\title{
European Neighborhood and Marshall Plan with Africa: aFederalist Point of View
}

\section{Paolo Ponzano}

The federalist thought is based at the same time on the theory of "raison d'état" (which has its origin in Machiavelli) and on the conception of world peace expressed by Immanuel Kant. On the one hand, the State is the irreplaceable instrument for making possible the coexistence of men in the framework of the societies based on the division of labor and the market economy (as were formed in Europe since the end of the Middle Ages). The market economy allows the development of a pluralistic and open society, but at the same time produces social inequalities and marginalization (just think of the current economic situation where $1 \%$ of the world's population possess $99 \%$ of the resources). Only the state's monopoly of force allows public power not only to ensure the safety of its citizens but also to impose mechanisms of regulation and solidarity in order to avoid private violence.

However, the development of national states has produced a situation of international anarchy, as all states try to make their national interests prevail over other states (think of President Trump's "America first" slogan, or the German "Deutschland über alles", or "d'abord les Français", or "primagli Italiani"). This spontaneous tendency has led States to exercise a power politics that often leads up ultimately to war. The Kantian conception of peace has made it clear that it must not beconfused with the truce between one war and another, but is configured as an organization of powers that overcomes international anarchy, transforming the balance of power between states into juridical relations, and makes war structurally impossible through the extension of state sovereignty to a universal scale (see Sergio Pistone's essay on this subject: "Federalism, Reason of State and Peace" - Spinelli Institute).

However, Kant could not identify, in his time, the institutional system through which to achieve perpetual peace (i.e. the federal state, which is a constitutional structure capable of achieving peace among all the federated states). Naturally, it would be utopian to imagine the establishment of a world government starting from the existence of 180 or more national States, as exist at present. There shall be a previous and progressive formation of regional or continental federations to which national States voluntarily delegate part of their sovereignty for the management of problems that can onlybe solved at supranationallevel(the European Union is the first institutional model of this type, to which other regional geopolitical realities are painstakingly following). As Sergio Pistone writes in his above-cited essay, a future European federation will tend to favor the development of the less-advanced countries first, and then of regional integrations (two organically related stages), because only by progressing in this direction will it be possible to remedy increasingly dangerous situations of instability, open up extensive markets and control "biblical" migrations, which otherwise will eventually become incompatible with a democratic progress in Europe (as confirmed by the current state of the migration phenomenon). 
Therefore, an unescapable choice will be in particular a great European "Marshall Plan" for the Southern Mediterranean, the Middle East and sub-Saharan Africa (already proposed by Altiero Spinelli in 1978, as indicated below). This plan - on the model of the American Marshall Plan of 1947, which allowed the launch of European integration - will have to make international aid, of an adequate size on both the economic and the security aspects, conditional on an area's development of regional integration and progress in human rights matters. The Marshall Plan - launched by the US Secretary of State on 5 June 1947 in a speech at Harvard University - was proposed to all European countries, but was accepted in 1948 by 16 Western European countries and by the Scandinavian countries (to which were added later the Federal Republic of Germany and Spain), while it was rejected by the Soviet Union and the countries of the communist bloc. In the first three years, the Marshall Plan granted $\$ 12$ billion (of which 5/6 as a gift and one sixth as a loan) up to a total of $\$ 17$ billion over the five years of its duration. It gave a strong boost to the European unification process, cemented the solidarity of the nascent western bloc and gave birth to the first organization of European cooperation (the OECE, later to become the OECD). Although, as Monnet wrote to Bidault, "it is illusory to think that sixteen sovereign countries will actually cooperate, and that only a federation of the West will allow us to solve our problems", nevertheless the creation of the OECE paved the way to successive European organizations. The Marshall Plan confirmed a general principle already present in the Roman world, expressed in Horace's first Epistle: "Tua res agitur, paries dum proximus ardet" ("it's your problem, when yourneighbor's wall is burning"). In fact, the Marshall plan prevented a persisting economic crisis in the European countries from producing high social tensions, that would have jeopardized the continent's economic and social rebirth (as well as the democratic system itself). As Marco Pannella said about twenty years ago, "if Europe does not take care of Africa, it will be Africa that will take care of us". Therefore, Europe should take responsibility for contributing to the economic development of the African countries (most of which, to tell the truth, are its former colonies, abundantly exploited in the past) and for promoting the creation of regionalintegration organizations.

The European Union started a neighborhood policy in 2003/2004 with its neighboring countries that do not have the vocation to become members of the EU. This policy, which was consecrated in the Lisbon Treaty (Article 8), aims to establish an area of prosperity and good neighborliness with 18 countries located at the eastern borders of the EU and in the Southern Mediterranean (from Ukraine to Algeria) through the conclusion of privileged association and partnership agreements. Association agreements have already been concluded by the European Union with most of the 18 countries, although the Union intends to intensify relations with all of the 18 countries covered by the neighborhood policy, in particular through specific action plans for each country. The Mediterranean countries covered by the neighborhood policy, with the exception of Libya, also participate in the Barcelona process, initiated by the 1995 Barcelona Declaration, which aimed to create a Euro-Mediterranean partnership (or Euro-Mediterranean union, as proposed by the then French President Sarkozy). According to the Dutch political scientist Steven Blockmans (see his essay "The Obsolescence of the European Neighborhood Policy", published by the Centre for European Policy Studies (CEPS), October 2017, Brussels), the neighborhood policy is currently in a phase of "hibernation", since the European Union chose to pursue a "realpolitik" which gives priority to its neighboring countries' security and stabilization interests, rather than to the values of democracy and protection of human rights that the Union declares to promote (Art. 2 of the Lisbon Treaty). The "Arab Springs", the conflicts in the Middle East and the spreading of terrorism have changed the attitude of the 


\section{Comments}

EU towards its neighboring countries, and the special relationship foreseen by the Lisbon Treaty has been replaced by the application of the EU foreign policy's global strategy to all countries.

The European Union and its Member States are the world's leading donors of public aid to development. Together, the EU and its Member States provided aid totaling 75.5 billion euros in 2016, which is around $60 \%$ of the total amount of aid granted during the year in question. In the same year, the European Union alone earmarked the sum of about 20 billion euros to development aid, of which the least developed and lowest income countries were the main beneficiaries. In September 2017, the European Union adopted the European Fund for Sustainable Development (EFSD), a central element of the Foreign Investment Plan which has already entered into force. With the Foreign Investment Plan, the European Union will for the first time give its support to stimulate public and private investment in Sub-Saharan African countries and in the countries of the European neighborhood, particularly in countries affected by conflicts, in those without access to the sea and in the less developed countries, where needs are more acute. The aforementioned Plan aims to combat the deep-rooted socioeconomic causes of migration, in particular irregular migration, and should contribute to the lasting reintegration of migrants in their own country of origin. The total European Union funding will amount to 4.1 billion euros from the European budget until 2020, a figure that should attract more than 44 billion euros of public and private investments during the period considered. If its Member States and other EU partners would contribute an equal amount, the total investment in the beneficiary countries could reach $€ 88$ billion (aimed to support the provision of energy and water resources, and the expenditure for the training of human resources, which are the essential elements of a plan for a sustainable growth of the African economy). Of course, the sums allocated by the European Union will not be sufficient to meet the sustainable development goals (SDGs) defined by the UN between now and 2030. Recent estimates indicate that the African continent would need an amount between 200 and 1200 billion dollars a year, for the sustainable development goals set by the UN to be achieved. The United Nations estimates that over the next 20 years 60 million young Africans will seek employment and must therefore be trained to find a job, while 75 million citizens will urbanize and will therefore need new housing. Another growth factor is the fact that Africa owns $60 \%$ of the world's arable land, though not all yet in use, and the largest reserves of mineral resources. Exploitation of this development-favoring potential is largely hampered by the non-availability of the necessary investments, in particular those to be used to bridge the infrastructural gap. 600 million Africans do not have electricity and lighting. The African Union has created an Electrification Agency, which has drawn up a plan to achieve the goal of full electrification of the continent in 10 years. The implementation of this plan would require a financial assistance from the EU of 5 billion dollars a year for the next 10 years, in order to generate a leverage effect on private investments up to the 250 billion dollars needed to realize the electrification plan. In addition, 300 million Africans do not have access to clean water, and only $5 \%$ of the arable land is properly irrigated. It should also be reminded that the acquisition of the largest oil field in Africa (over 9 billion barrels of crude oil) - placed in front of the coast of Nigeria, where 12 million slaves departed from for the Europeans' colonies in America-cost the huge sum of 1.1 billion dollars, invested by European oil and gas companies. This amount would have been sufficient to cover more than $80 \%$ of Nigeria's total health care expenditure for 2015. Yet, Nigerian citizens have not benefited from the agreement, which 
has benefited instead only a limited number of corrupt officials and money launderers. That project is certainly not an isolated case. The natural resources present in most of the African countries are transferred through offshore companies that, to a large extent, are connected to companies and businessmen operating in America and in Europe. As confirmed by the documents emerging from the "Panama Papers", anonymous companies, with theconnivance of local dictators and tax havens, are used as tools aimed at draining the natural wealth present in Africa and in some of the poorest countries in the world. Only by opening Europe to products made - or at least semi-finished - in Africa, while guaranteeing an equitable distribution of profits, and addressing the structural causes that undermine the development capacity of millions of people, will it be possible to implement a European development policy based on sustainable solutions.

Finally, let us not forget that the African population will increase from one billion 186 million people in 2015 to two billion 478 million in 2050, and to about four billion at the end of the century, while the demographic forecasts for the European Union see a decrease of its population starting from 2050.

Given this demographic situation, it would be illusory to think of a decrease in African migration to Europe in the coming years, and it is also illusory to say that we want to repatriate all the illegal immigrants to their countries of origin. For example, Italy has concluded re-admission agreements with only four African countries (Egypt, Morocco, Tunisia and Nigeria), so it would be illusory to repatriate migrants to other African countries. As Emma Bonino pointed out, how could we repatriate 600,000 migrants, called illegal immigrants, from countries with which we do not have readmission agreements? Moreover, as not everybody knows, the remittances of migrants to their countries of origin amount to a global figure of about $\$ 31$ billion a year, three times higher than the amount of aid provided to the countries in question (while the multinationals operating in the African continent "reimport" about \$32 billion a year of profits to their countries of origin). How can we imagine that the leaders of those countries will relinquish spontaneously and without compensation such an amount of resources? In this situation, the need for Europe to launch a development plan for and with Africa is evident. Altiero Spinelli already formulated in 1978 a visionary proposal after the monetary crisis of 1971 and the oil crisis of 1973. "The North" - wrote Spinelli - should make to the "South" the great proposal of transferring every year, free of charge or at very favorable conditions, monetary means to be used not only to meet the needs of hungry populations, but for the implementation of development plans, prepared by the countries themselves, if necessary with technical assistance provided by the advanced countries (...). The only condition that should be asked - specifies Spinelli

- is that we should propose"development plans for open-type economies". The realistic nature of the proposal lies in the fact that the plan must serve to promote the development of both the countries of the South and those of the North of the world. The advanced countries should implement for themselves "austerity" policies, "so that it would be possible to allocate for many years a considerable fraction of their saved income to investments in development plans of countries of the South of the world (...).

If the operation will be successful, those countries will begin not only to increasingly consume investment goods and consumer goods, but also to create modern industries and farming practices. Their demand for goods, especially machine tools and technologies, will increase; it will be addressed to the developed countries, and the Western economy will be put in motion again, not so much because it will be decided in the abstract to increase production, but because there will be to produce more to respond to a growing demand not destined to being exhausted so soon. 
In conclusion, the realization of the equivalent of a Marshall Plan for and with Africa requires at least two basic political requirements. The first is the restoration of political stability and security conditions in those African countries from which migratory flows mainly originate (through a renewed EU foreign policy, based on the guidelines outlined in the new "Global Strategy for the EU" proposed by Federica Mogherini). In turn, to be successful, Africa's development plan will have to be managed through a regional organization, including the Mediterranean countries and the Saharan and sub-Saharan African countries; it will be responsible for elaborating the guidelines of the plan and for selecting the investments to be made, and it should act in close connection with the institutions of the European Union. To this end, it would be desirable to see the rise of a new Jean Monnet in Africa, who could launch the creation of an African Economic Community for water and renewable energies. 